\title{
加工硬化特性を考慮したハニカム材の面内圧潰変形*
}

\author{
（第 1 報, 数值解析的検討)
}

\author{
陳 玳 珩*1, 小河卓也*2, 尾崎伸 吾*3

\section{In-Plane Compressive Deformation of Honeycomb Structure in Consideration of Work-Hardening Effect \\ (1st Report, Numerical Investigation)} \\ Dai-Heng CHEN $^{* 4}$, Takuya OGAWA and Shingo OZAKI \\ ${ }^{* 4}$ Department of Mechanical Engineering, Tokyo University of Science, \\ 1-3 Kagurazaka, Shinjuku-ku, Tokyo, 162-8601 Japan

\begin{abstract}
In this paper, the crushing behaviour of hexagonal honeycomb structures with finite widths and heights subjected to in-plane compressive loading is studied by using the finite element method. It is found that stress-strain curves are clasiffied roughly into two types, which include both symmetric and asymmetric modes. They are influenced by ratio of thickness of cell wall, ratio of the workhardening, and ratio of the yield stress. In addition, it is revealed that the deformation mechanism of the honeycomb structure with the finite width and the height can be explained by the unit model proposed by Klintworth (1988), even if the effect of the work-hardening is considered.
\end{abstract}

Key Words: Finite Size, Hexagonal Honeycomb Structure, Buckling, Finite Element Method, Work-Hardening, Deformation Mode

\section{1. 緒言}

八ニカム材に面内負荷を与えると，様々な座屈モー ドが発生することが多くの解析や実験的研究により明 らかにされている(1) (4). 中でも Klintworth ${ }^{(5)}$ は，八 二カム材の 1 つの六角形セルの変形について, その座 屈変形様子から座屈モードを mode I 〜VIに分類し， それぞれの発生に対する幾何的条件および応力的条件 （面内応力の 3 つの成分の組合せ）を検討すると同時 に, 座屈後の圧縮応力-ひずみ関係の理論式を求めた. なお，Klintworth ${ }^{(5)}$ が提案した I 〜VIの座屈モードを 大別すれば，基本的には対称モードと非対称モードに 分けることができる. Klintworth ${ }^{(5)}$ の研究によれば, 六角形セルの縦壁と同じ方向の 1 軸圧縮においては, 八ニカム材の軸圧潰変形は常に非対称モードである.

他方, Karagiozova and $\mathrm{Yu}^{(6)}$ はセル壁の相対厚さ $t / l$ が比較的大きい場合のハニカム材を用い，2軸応力下 の塑性座屈モードについて詳細な検討を行った．それ によれば, 塑性座屈の基本モードとして, 変形が対称 的である mode C, 変形が非対称的である mode $\mathrm{S}$ ，さ

* 原稿受付 2008 年 4 月 4 日

*1 正員, フェロ一, 東京理科大学工学部機械工学科(丞 162 8601 東京都新宿区神楽坂 1-3).

*2 元: 東京理科大学大学院工学研究科学生.

*3 正員, 横浜国立大学工学研究院システムの創生部門(画2408501 横浜市保土ヶ谷区常盤台 79-5).

E-mail : chend@rs.kagu.tus.ac.jp
らに変形が花状となる mode $\mathrm{F}$ があるが, 応力比 $\sigma_{y} / \sigma_{x}$ （y方向はセルの縦壁と同じ方向である）が 1 より小さ い場合，変形は mode $\mathrm{C}$ となり， 1 に等しい場合に変 形は mode F となり，1 より大きい場合に変形は mode $\mathrm{S}$ となる. したがって, Klintworth ${ }^{(5)}$ の研究と同様に, 六角形セルの綐壁と同じ方向の 1 軸圧縮においては, 八ニカム材の軸圧潰変形はつねに非対称モードである.

しかし, Papka and Kyriakides ${ }^{(2)}$, Klintworth and Stronge $\mathrm{e}^{(7),(8)}$ に代表されるハニカム材の 1 軸圧縮の 実験結果によれば，その座屈変形はまず対称モードで あり，その後非対称モードに遷移する。このことは， 以上に述べた理論研究から説明できない，なぜなら Klintworth ${ }^{(5)}$ と Karagiozova and $\mathrm{Yu}^{(6)}$ の研究は，いず れも材料を加工硬化のない弾完全塑性体としており, かつ周期的な境界条件を想定した無限大の八ニカム材 を解析対象としているからである. したがって，八ニ カム材の圧潰挙動をより正確に把握するには，その材 料の加工硬化特性および有限な大きさによる影響も考 慮にいれる必要がある.

そこで本研究では，有限幅および高さを有し，かつ 加工硬化を考慮した弾塑性ハニカムコア材を対象に, 面内方向の 1 軸圧縮変形に対する有限要素法数值シュ ミレーション解析を実施するとともに，圧縮変形モ一 ドならびに圧縮荷重-変位特性に注目し，材料・幾何 
特性および境界による影響について系統的な検討を 行った.

\section{2. 数值解析方法}

本研究では, 有限要素法沉用コードMSC.Marc ${ }^{(9)}$ を 用いて，右阻幅执よび高きを有するハニカム材の圧潰 挙動の弾塑性有限変形シュミレーションを行った. 具 体的な解析手法として, 図 1 に示すような縦 9 段, 横 20 列, セル数 180 の六角形八ニカム材を基本モデルと

し, 移動剛体壁により強制変位を与えることで $y$ 方向 に 1 軸圧潰している.ここで, 六角形のセル壁の厚さ を $t$, 縦セル壁の長さを $h$, 斜めセル壁の長さを $l$, 斜 めセル壁の傾き角を $\theta$, 有限八二カム材幅 $B$ および高 さ $H$, 奥行き $c$ とする (本研究では $l=h, \theta=30^{\circ}$ の 正六角形八ニカムとして検討を行う). また，下端の $y$ 方向変位を拘束し， 1 節点のみ $x$ 方向を拘束した. モ デル化に関しては, セル壁の座屈変形が滑らかに行わ れるように留意し, 分割はセル壁の軸方向に 4 分割, 要素は 3 節点梁要素（要素番号 45）を用いることで 有限要素離散化した。 また簡単のため, 八ニカム材と 剛体壁間の摩擦による影響は無視し, 2 次元条件下で の検討を行う.

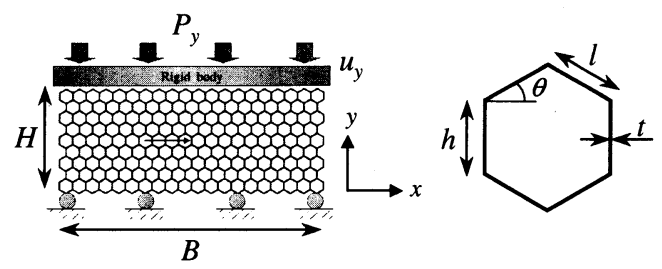

Fig. 1 Basic model of honeycomb structure

加工硬化特性として, 次式で与えられる 2 直線硬化 則を採用した.

$$
\sigma_{y}=\sigma_{0}+\frac{E_{s} E_{h}}{\left(E_{s}-E_{h}\right)} \varepsilon^{p}
$$

ここに， $\sigma_{y}$ は降伏応力, $\sigma_{0}$ は初期降伏応力, $\varepsilon^{p}$ は相 当塑性ひずみであり， $E_{s}$ および $E_{h}$ はそれぞれ材料の 緥弾性係数および加工硬化係数を表している. 本解析 で用いた材料特性および幾何特性に関して, 表 1 にま とめている.

次節での検討を行う際, 次式で与えられる無次元化 した圧縮変位と圧縮荷重をそれぞれ圧縮ひずみ $\varepsilon$, 圧 縮応力 $\sigma$ と定義して用いる.

$$
\begin{gathered}
\varepsilon=u_{y} / H \\
\sigma=P_{y} /(B c)
\end{gathered}
$$

ここに, $P_{y}, u_{y}$ はそれぞれ $y$ 方向圧縮荷重, 圧縮変位 としている.

また，八ニカム材の塑性開始応力として $\sigma_{p}$ を以下 のように定める ${ }^{(1)}$.

$$
\sigma_{p}=\frac{2}{3}\left(\frac{t}{l}\right)^{2} \sigma_{y}
$$

Table 1 Analytical parameters

\begin{tabular}{c|c}
\hline Young's modulus $E_{s}[\mathrm{GPa}]$ & 70.6 \\
\hline Ratio of yield stress $\sigma_{0} / E_{s}$ & $0.001,0.003,0.010$ \\
\hline Ratio of work hardening $E_{h} / E_{s}$ & $0.0-0.05$ \\
\hline Ratio of cell wallthickness $t / l$ & $0.03-0.20$ \\
\hline Poisson's ratio $v_{s}$ & 0.3 \\
\hline
\end{tabular}

\section{3. 数値解析結果および検討}

3.12 種類の圧潰特性図 2 および 3 に相対 厚さがそれぞれ $t / l=0.06$ および $t / l=0.20$ の 2 通 りのハニカム材について, 数值シミュレーション解 析で求めた有限八ニカム材の圧縮応力-ひずみ曲線を 示す. ここで，加工硬化係数による影響をみるため に, $E_{h} / E_{s}=0,0.01,0.03$ とした. また降伏応力比は $\sigma_{0} / E_{s}=0.003$ とした. 図からわかるように, 圧縮応 力ーひずみ曲線は厚さおよび加工硬化係数によって異な るが，基本的には図 4，5 の図中に模擬的に示すよう に2つのタイプに大別することができる.この異なる タイプの圧縮応力-ひずみ曲線に対応する変形の様子 を検討するために, 図 4, 6 では, $t / l=0.20, E_{h} / E_{s}=$ $0.01, \sigma_{0} / E_{s}=0.003$ の場合をタイプ I の例として, 図 5,7 では, $t / l=0.06, E_{h} / E_{s}=0.01, \sigma_{0} / E_{s}=0.003$ の 場合をタイプ II の例として，それぞれの圧縮応力-ひ ずみ曲線と圧縮過程における変形の様子を示す。ここ で, 図 6 では位置 A での一つの六角形セルの変形の様 子の移り変わり (a) (d) を, 図 7 では, 圧縮過程 (a) での位置 A，B，Cにおける変形の様子を示している.

図 4 からわかるように, タイプIでの変形は 4 つの 段階 (i) (iv) に分けられる.まず第 1 段階では, 左右 端部の縦セル壁に微小曲げ変形が見られるが, 図 6 の 変形様子に示されるように全体的にセルの変形は縦セ ル壁が回転変形を行わない対称モードとなる．また， このとき圧縮応力は上昇する. 第 2 段階では, 左右端 部の綐セル壁の曲げ変形が大きくなり, 対称性が崩壊 し, 縦セル壁が回転変形を行う非対称モードに変形が 遷移する．このモード遷移は各々のセルでほぼ同時に 行われるため, 応力-ひずみ曲線は第 1 段階と異なる特 徵を示す. 第 3 段階では, 変形の局所化が始まり, 中 間にある一横列に大きい変形が集中する.このため応 力は急激に低下寸る. そして, 第 4 段階では, 局所変 


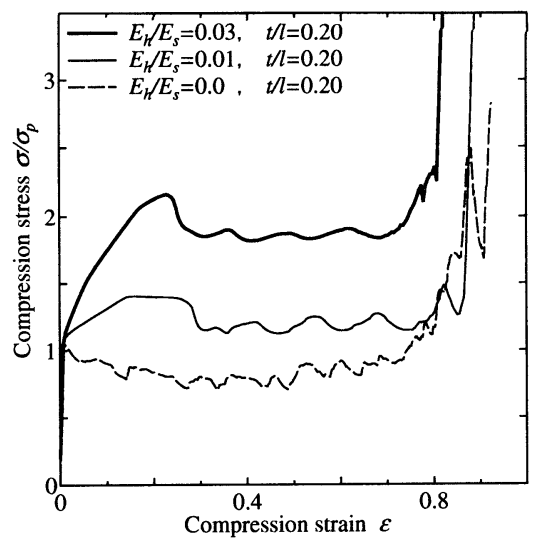

Fig. 2 Stress-strain curves of finite honeycomb with $t / l=0.06$

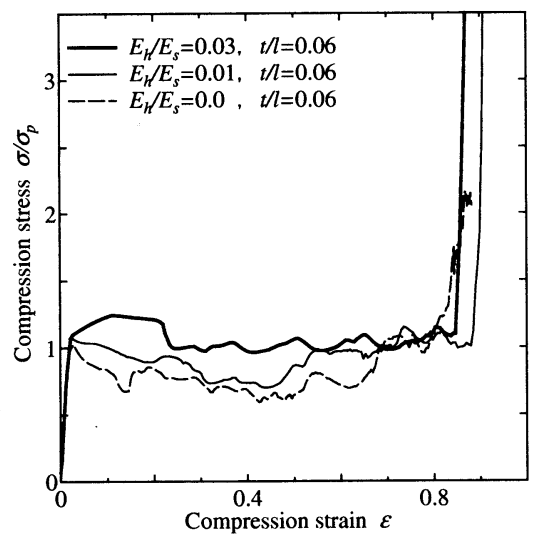

Fig. 3 Stress-strain curves of finite honeycomb with $t / l=0.20$

形が集中した横列は圧潰され, 緻密化により圧縮応力 が上昇するが，すぐに隣り合う次の列に局所変形が集 中するようになる.この繰り返しのため, 圧縮応力は 一つ一つの横列の圧潰に伴い周期的に一定の幅で上下 し振動する, 所謂 Gibson and Ashby ${ }^{(1)}$ が指摘したプラ ト一領域に対応する.この変形過程は, Klintworth and Stronge $^{(7),(8)}$ による実験や Papka and Kyriakides ${ }^{(2)}$ の 実験や解析結果でも確認されているが，この対称モー ドから非対称モードへの変形の遷移は, Klintworth ${ }^{(5)}$ やKaragiozova and $\mathrm{Yu}^{(6)}$ の理論研究からでは説明でき ない.

他方, 図 5 からわかるように, タイプII での変形 は2つの段階 (i), (ii) に分けられる.まず第 1 段階で は, 図 7 に示した位置 $\mathrm{A}, \mathrm{B}, \mathrm{C}$ でのセルの変形様子 から 3 種類の変形の様子が確認できる. すなわち, 位

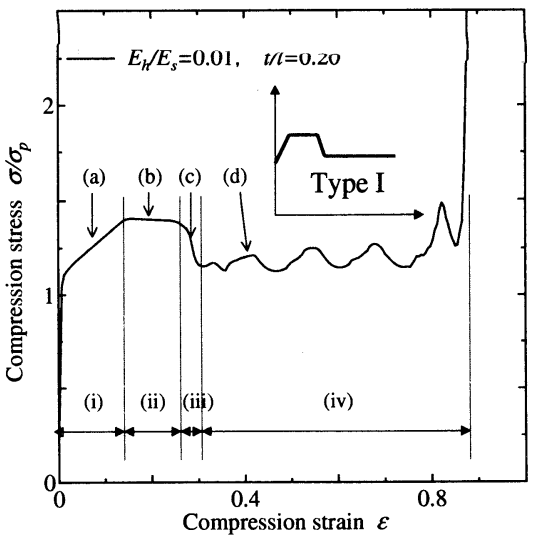

Fig. 4 Typical stress-strain curve of Type I

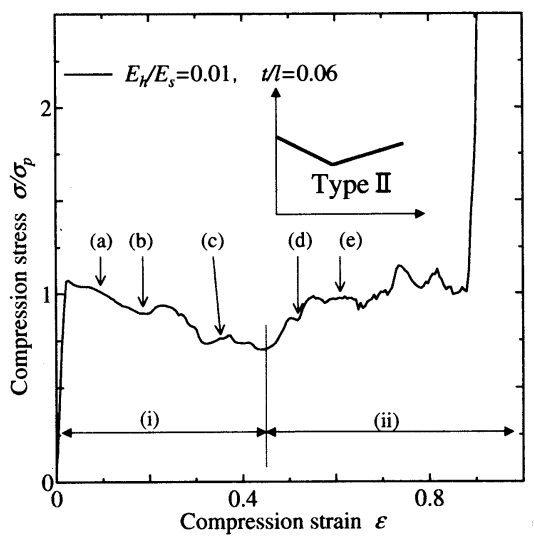

Fig. 5 Typical stress-strain curve of Type II

置 A ではほとんど変形せず対称性を維持している対 称モード, 位置 B では縦セル壁の回転方向が交互とな る，Klintworth ${ }^{(5)}$ が指摘した非対称モード，さらに位 置 Cにおいては位置 B の非対称モードとは異なった， 縦セル壁の回転方向が同方向となる非対称モードであ る.ここでは位置 B での非対称モードを交互非対称型, 位置 Cでの非対称モードを平行非対称型と呼ぶ. 平行 非対称型のセルは図 8 の模擬図に示すように，対角線 方向に角部よりせん断変形が局所的に卓越する層（以 下，せん断層と称する）を形成する.このせん断層の 起点の角部付近ではセルは圧潰し交互非対称型の変形 となり，せん断層が形成されていない図中の左上・右 下角部では対称モードとなる．変形は主にせん断層に 集中するため圧縮応力は加工軟化を伴い低下するが， 角部より局所化が対角線に沿って伝播することにより 圧縮応力は振動する．また図 8 において，角度 $\alpha$ は対 角線と水平方向とのなす角であり, 角度 $\beta$ はせん断層 
(a)
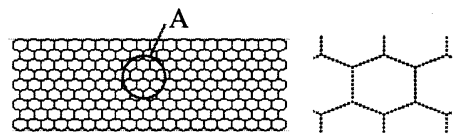

(b)

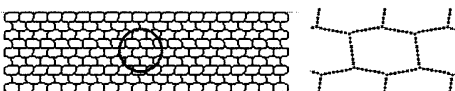

(c)

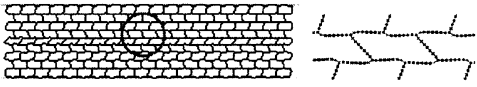

(d)
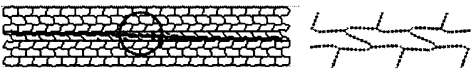

Fig. 6 Deformation process of Type I honeycomb (a)

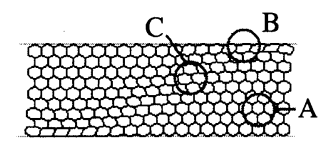

(b)

(c)
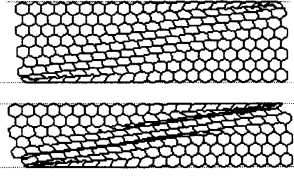

(d)

(e)
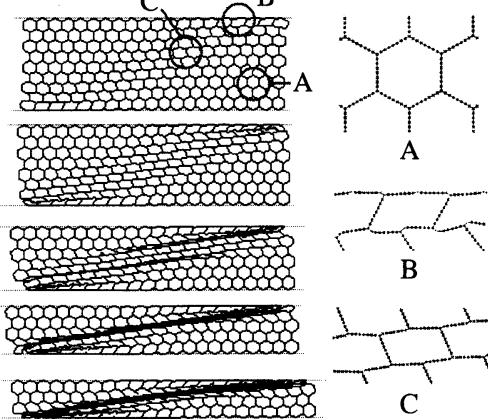

A
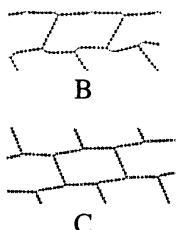

C
Fig. 7 Deformation process of Type II honeycomb

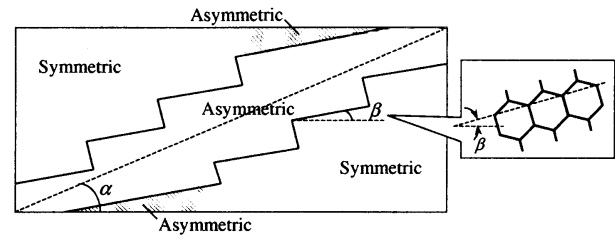

Fig. 8 Schematic representation of deformation in Type II honeycomb

にある斜めになったセル層と水平方向のなす角である (変形初期には $\beta=0$ ). よって圧縮に伴い角度 $\beta$ は增 加する. 一方, 角度 $\alpha$ は圧縮に伴い減少する. この 2 つの角度が $\alpha=\beta$ となった時, 変形は一つの層に集中 し，その層の緻密化により変形は第 2 段階へと移る. また, 第 2 段階では, 非対称変形の層が緻密化に至る ため, 対称モードの領域に変形が集中し, 圧縮応力は 上昇する.

以上より, 単体モデルと有限幅のモデルの異なる点 として, 前者は周期性を厳密的に満たしているが, 後 者は, 有限幅であるために, 左右の自由境界に近いハニ カムと中央にあるハニカムの変形は境界の影響によっ て微妙に異なることが挙げられる. したがって, 圧縮
初期において, 有限幅のモデルでは各ハニカムの変形 の微小な相違が幾何的な不整の役割を担い，図 6,7 のような非対称変形や局所的な変形を誘発する. その 結果, 有限な大きさを持つハニカム材では相対肉厚さ や加工硬化により圧縮応力-ひずみ曲線が異なり, 無限 大のハニカム材ではみられない圧潰変形が生じる. 以 下では, これらの現象を Klintworth ${ }^{(5)}$ やKaragiozova and $\mathrm{Yu}^{(6)}$ らが理論検討を行った周期境界を利用した無 限大のハニカム材を用いて説明が可能か，もしくはど こに相違点があるのかについて詳細に検討していく.

3.2 変形モードマップ種々の肉厚比 $t / l$ および 加工硬化係数 $E_{h} / E_{s}$ の組み合わせについて, 八ニカム 材の圧潰時における応力-ひずみ曲線を求め, 得られた 曲線に基づいてそのタイプを整理すると，図9のよう な変形タイプを示すマップが得られる. 図からわかる ように, 加工硬化係数または相対肉厚さが増加すると 変形はタイプI となる傾向がみられ, また, 降伏応力 については図中に示すように降伏応力比を 0.001 から 0.003 に変更するとタイプ I とタイプ II の境界線（点 線）は上に移動する.

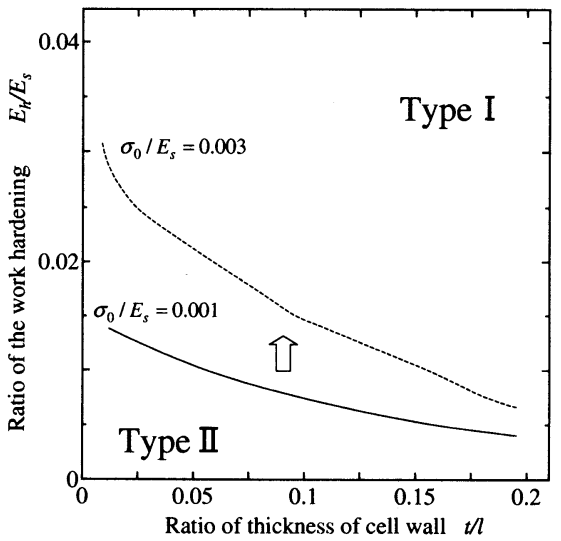

Fig. 9 Classification chart of type

3.3 一般的なハニカム材による検討 以上の解 析において縦セル壁は斜めセル壁と同じ厚さとしてい る ${ }^{(10)}$. しかし, 一般的なハ二カム材は, 製作方法に より縦セル壁の厚さが斜めセル壁の 2 倍の厚さとな ることがよくある.ここで前者と後者をそれぞれ $t-t-t$ model と $t-t-2 t$ model と名づけて, それらのモデルに ついて解析を行った.

図 10，11 は，タイプI，II の例として，相対肉厚さ $t / l=0.20, t / l=0.06$ における $E_{h} / E_{s}=0.01, \sigma_{0} / E_{s}=$ 0.003 での両モデルの応力-ひずみ曲線を示したもので ある. その結果, タイプIでは, 第 2 段階までの荷重 


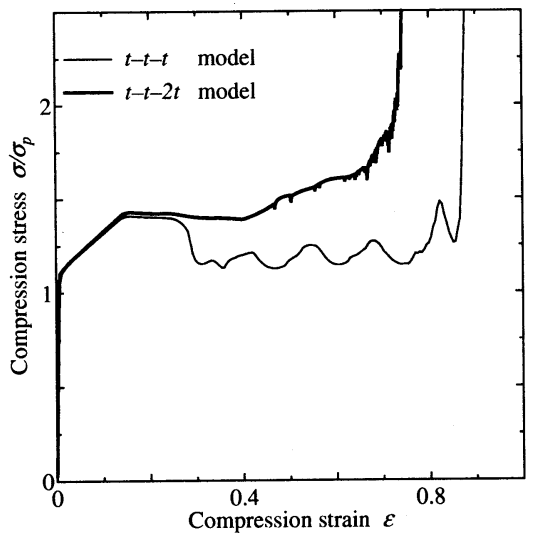

Fig. 10 Stress-strain curves of Type I

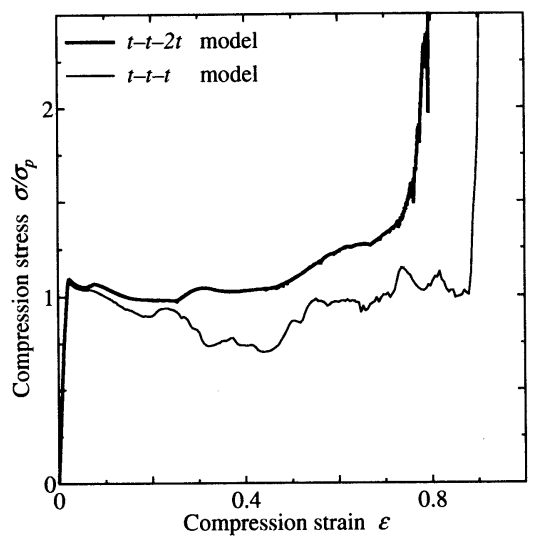

Fig. 11 Stress-strain curves of Type II

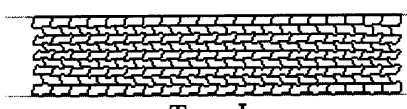

Type I

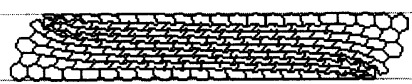

Type II

Fig. 12 Deformed shapes of $t-t-2 t$ model at process (d) in Figs. 4 and 5

が同じであるが，第 3 段階に対応する荷重降下がなく なった. またタイプII では, 最初のピーク荷重は同じ であるが，圧潰過程での荷重は全体として大きくなっ ている. 図 12 に $t-t-2 t$ model $の$ 変形の様子を示す.こ こに, タイプI の変形の様子は図 4 の過程 (d), タイ プ II の変形の様子は図 5 の過程 (d) に相当する. 図 12 より, タイプI の過程 (d) では局所化は生じず, 緻密

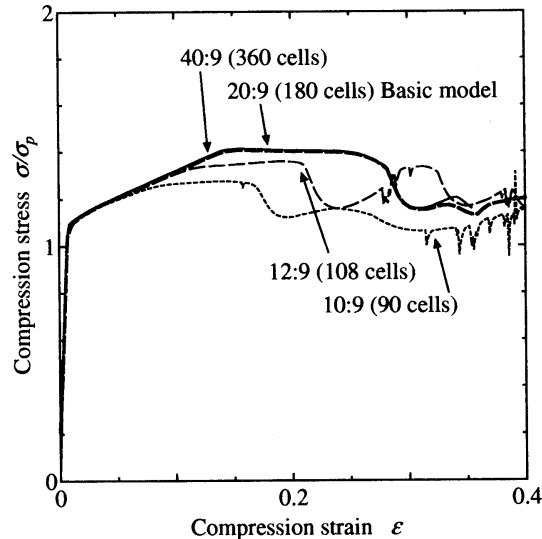

Fig. 13 Stress-strain curves for various honeycomb width with $t / l=0.20$

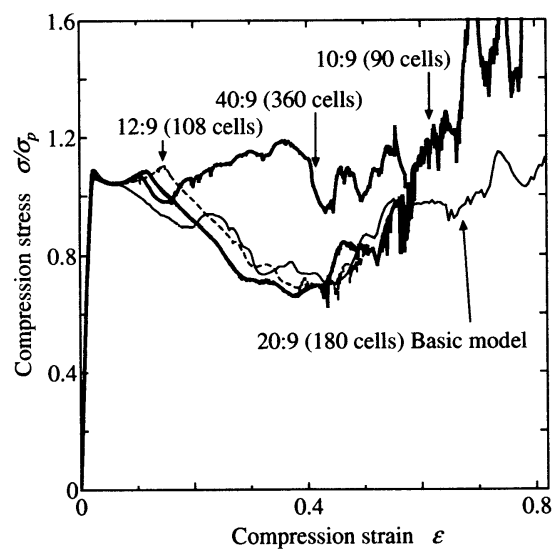

Fig. 14 Stress-strain curves for various honeycomb width with $t / l=0.06$

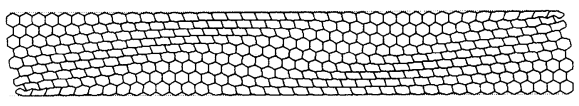

Fig. 15 Deformed shape of Type II honeycomb with 40:20 model

化に至らないことがわかる. 他方，タイプII の変形で は角部に局所化は生じるが縦セル壁厚さを 2 倍にする ことにより圧縮に対する抵抗が大きくなるため, $t-t-t$ model と異なり局所化は進展しない. したがって，タ イプI, II のいずれのハニカム材も縦セル壁厚さに依 存せず，相対肉厚 $t / l$ によって整理できるが, 縦セル 壁厚さを 2 倍にすることにより非対称変形での荷重降 下が生じなくなるため, タイプ I では局所化が発生せ 
ず, タイプII では局所化が伝播しなくなったといえる.

また, Klintworth ${ }^{(5)}$ や Karagiozova and $\mathrm{Yu}^{(6)}$ がセル 単体の解析に基づいて予想した変形と異なり, 有限幅 および高さを持つ八ニカム材の圧潰変形において, 夕 イプIでは対称モードから非対称モードへのモードの 遷移が生じるが, タイプII では, 対称モードの領域と 非対称モードの領域が混在する.このような変形特徵 に対するハニカム材の幅と高さの影響をみるために, 本研究では, 図 1 に示した綐 9 段横 20 列の基本モデ ルのほかに, 横を 10 40 列と変化させたモデルにつ いても同様に数值シミュレーション解析を行った. 図 13 および 14 に相対肉厚さ $t / l=0.20$ および $t / l=0.06$ の条件下で列数を変化させた際の圧縮応力ーひずみ曲 線を示す.ここに，それぞれの曲線を区別するため, 横セル数 : 縦セル数の比で凡例を与えている. タイプ Iにおいては, 各段階 (i) (iv) における変形は基本的 には同じであるが, 横列数を増やし幅を大きくするほ ど第 2 段階一移る時期が遅まる. なお， 20:9 モデルと 40:9 モデルの圧縮応力-ひずみ曲線が重なることから 上限は存在すると推察される.一方, タイプII では, 幅が大きくなると図 14 中の 40:9 に示すように 20:9 モ

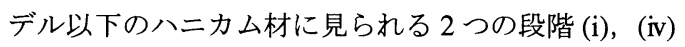
が見られなくなった. その要因としては図 15 の 40:9 モデルの変形の様子に示されるように, 幅の増加に伴 いセルの安定性が増し, 局所化進展が抑制され, 対角

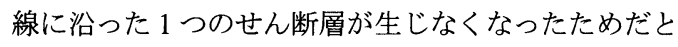
いえる.

\section{4. 単体モデルによる検討}

本節では, 有限幅を有するハニカム材の圧潰挙動を 無限大の八ニカム材と比較するため, 周期的な境界条 件を想定したセル一個の変形に注目し検討を行う。具 体的には, 図 16 に示す Honig and Stronge ${ }^{(3)}$ が圧潰荷 重の理論値の正当性を判断するために考案した単体モ デルを用いて数值シュミレーション解析を行った(モ デルの詳細設定は, Honig and Stronge ${ }^{(3)}$ の 82.3 を参 照されたい).

まず, 有限八ニカム材の基本モデルと単体モデルの 数值シュミレーション解析によって求めた圧縮応力ひずみ関係を比較する. 図 17 および 18 にそれぞれ夕 イプIおよびII となる $t / l=0.20$ および 0.06 の圧縮応 カーひずみ曲線を示す．図にはそれぞれの相対肉厚さ の単体モデルに対して, 対称型変形と非対称型変形を 呈した圧縮応力-ひずみ曲線と有限八二カム材の応力ひずみ曲線が示してある.ここで, 単体モデルの圧縮 応力ーひずみ曲線は, 非対称変形を生じさせるために

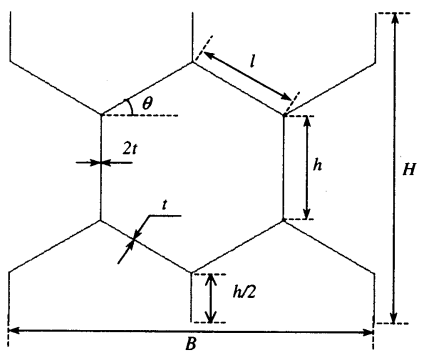

Fig. 16 Unit model for FEM

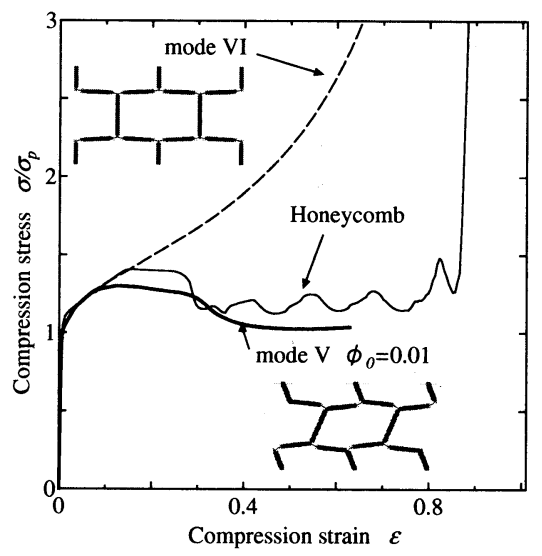

Fig. 17 Stress-strain curves in unit model and honeycomb structure (Type I; $t / l=0.20$ )

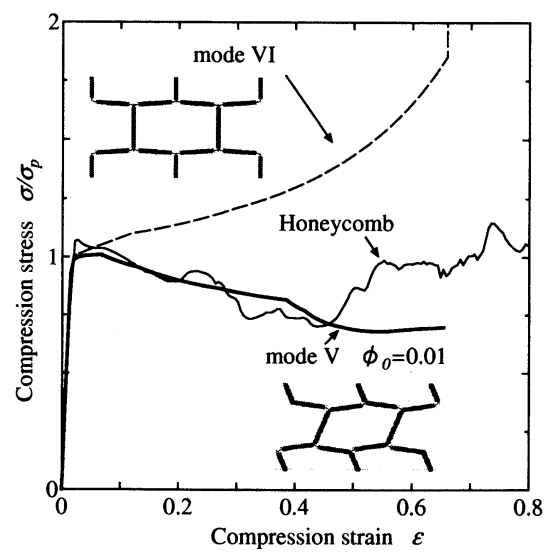

Fig. 18 Stress-srain curves in unit model and honeycomb structure (Type II; $t / l=0.06$ )

Honig and Stronge ${ }^{(3)}$ と同様に各綐セル壁に微小な回転 角 $\phi_{0}$ (縦セル壁と $y$ 軸とがな寸角度) をつけて求めたも のであるが，図には $\phi_{0}$ の影響がほとんど見られなく なる $\phi_{0}=0.01^{\circ}$ を採用している. 


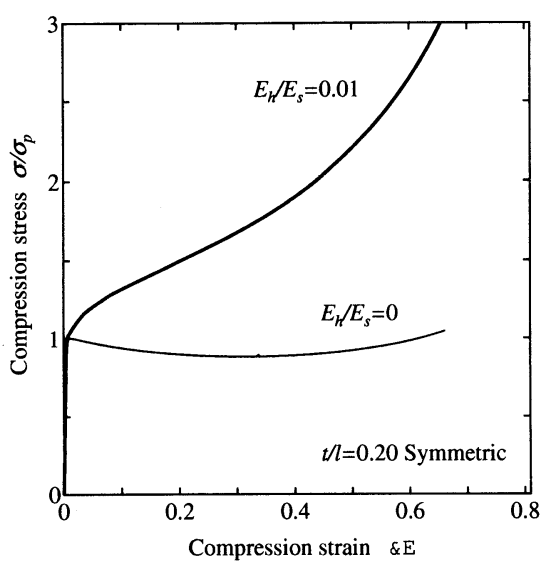

Fig. 19 Stress-strain curves of unit model with $t / l=$ 0.20 ; symmetric mode

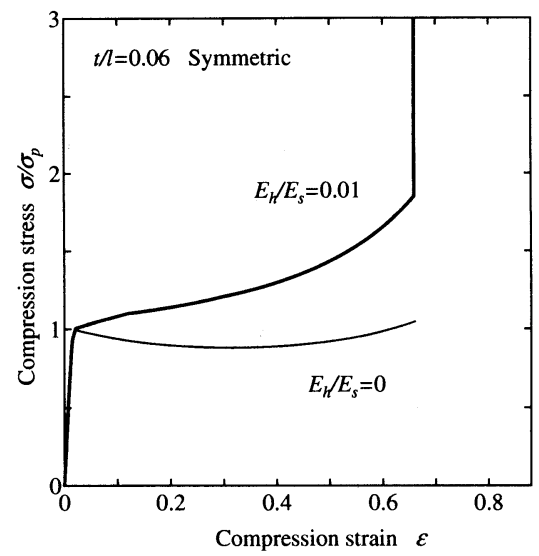

Fig. 20 Stress-strain curves unit model with $t / l=0.06$; symmetric mode

図 17 からわかるように，タイプ I での第 1 段階の 変形は両モデルで同じである．第 2 段階では圧縮応力 值はほぼ一致するが，単体モデルの方が低い值を示す. その理由として, 単体モデルにおいては縦セル壁の回 転により非対称の変形モードを生じるように対称では ない境界条件を設定しているが，有限八ニカム材の解 析では対称の変形を生じるように境界条件を設定して いることが挙げられる.これは，第 1 段階から第 2 段 階への有限八二カム材の移り変わりにおいては，中央 部から非対称変形が徐々に広がり, 詳細にみると対称 モードの領域がいくらか残っており，さらには，相対 厚さの減少に伴い単体モデルの荷重は下がり, それに より対称モードは見られなくなったことからも確認で

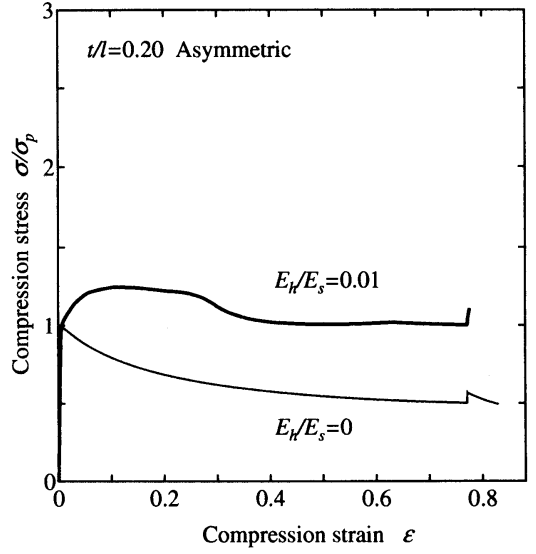

Fig. 21 Stress-strain curves unit model with $t / l=0.20$; asymmetric mode

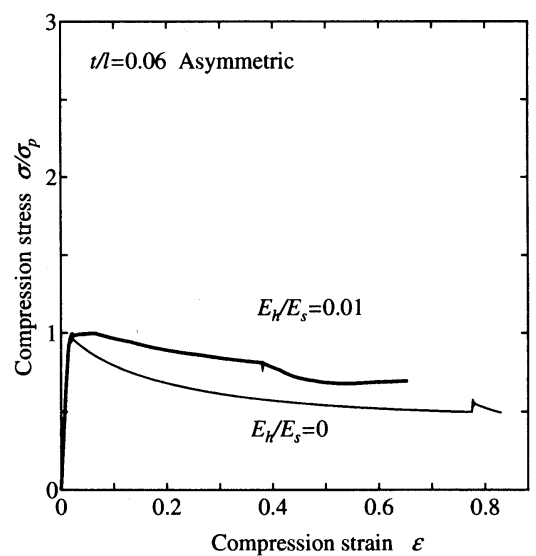

Fig. 22 Stress-strain curves unit model with $t / l=0.06$ : asymmetric mode

きる.

タイプ II では最小応力値の時期は早まるが, 単体モ デルにおける非対称変形モードにより，第 1 段階での 応力-ひずみ曲線が表現可能である．前節で述べたよう に，タイプII では図 8 のように変形においてセルが対 称モ一ド, 平行非対称モード, 交互対称モードの 3 種 類のモードが混在する変形過程をとる. しかし, 対称 モードは非対称モードに比べ剛性が高いため, 変形は 主に対角線に沿ったせん断層に集中する，よって，圧 縮変位 $u_{y}$ を有限八ニカム材の高さ $H$ で除して得たひ ずみは，せん断の層にあるセルのひずみそのものより 小さいゆえに, 最小忘力值は早期に現れることとなる.

図 19 22 に相対肉厚さ $t / l=0.06, t / l=0.20$ での 
単体モデルによる非対称, 対称モードの圧縮応力-ひず み曲線を示す．ここで加工硬化の影響をみるため, 加 工硬化係数比 $E_{h} / E_{s}=0$ および 0.01 の条件下で解析を 行った. 相対肉厚さ $t / l=0.20$ の有限八ニカム材の圧 縮応力-ひずみ曲線は, 図 3 より加工硬化がない場合 はタイプII となり, 加工硬化係数比 $E_{h} / E_{s}=0.01$ の場 合はタイプI となることがわかっている. 一方, 図 19, 21 より, 単体モデルにおける応力-ひずみ曲線に注目 すれば，加工硬化を大きくしたことにより対称モード， 非対称モードともに非対称変形による応力低下が生じ なくなり, 対称変形による応力上昇が確認できる.す なわち, 無限大のハニカム材と有限なハニカム材では 加工硬化による影響は等しいといえる. また, 相対肉 厚さ $t / l=0.06$ の有限八ニカム材の圧縮応力-ひずみ曲 線は, 図 2 より加工硬化係数比 $E_{h} / E_{s}$ を 0.01 まで増 加させても変化はみられないことがわかっている. 一 方, 図 20, 22 より, 単体モデルでは非対称モードに は変化は見られず, 対称モードでは応力上昇が生じる 様子が確認できる.しかし，前述したように，タイプ II では第 1 段階において変形は主にせん断層での非対 称モードに集中するため，対称モードの影響はほとん どないといえる.

以上より, 有限なハニカム材における変形メカニズ ムは周期的な境界条件を想定した単体モデルにより解 明でき, 加工硬化による影響は等しいといえる.

\section{5. 結言}

本研究では, 有限要素法による数值解析結果に基づ き, 有限な幅および高さを有し, かつ加工硬化を考慮 したハニカム材の圧潰挙動について検討を行った．そ の結果, 以下の知見が得られた.

(1) 1 軸圧縮を受ける有限八ニカム材の圧縮応力-ひ ずみ曲線は, その変形挙動からタイプI とタイプ II に大別できる. 相対肉厚 $t / l$ が大きく, また加 工硬化係数が大きい場合, タイプ I となる傾向が みられ, 相対肉厚が小さく, また加工硬化係数が 小さい場合，タイプII となる傾向がみられる.

(2) タイプI では Klintworth ${ }^{(5)}$ や Karagiozova and $\mathrm{Yu}^{(6)}$ の理論研究からでは説明できない対称モー ドから非対称モードへの遷移が生じ, その後, 変 形が横列のある層に集中し, 圧縮応力は振動しな がらほぼ一定となることを明らかにした。一方, タイプII においては, 対称モード, 非対称モー ドが混在し, 非対称モードの領域は対角線に沿っ てせん断変形が局所的に集中したセルの層（せ ん断層）を形成し，変形は主にそこに集中するた
め, 加工軟化を伴い圧縮応力が低下する. また, Klintworth $^{(5)}$ が提案した非対称モードとは異なる 平行非対称型の変形モードがこのせん断層には存 在することを示した.

(3) 有限な大きさのハニカム材について, タイプI では, 各圧潰過程における変形は基本的には同じ であるが，横列数を増やし幅をある程度まで大き くすると第 2 段階へ移る時期が遅まることを示し た. また, タイプII では, 幅がある程度大きくな

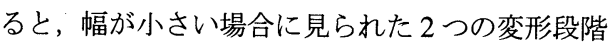
が見られなくなった. その要因としては幅の増加 に伴いセルの安定性が増し, 局所化の進展が抑制 され，対角線に沿ったせん断層が生じなくなるこ とを明らかにした。

(4) 有限な大きさのハニカム材の圧縮応力-ひずみ曲 線は, 非対称モードと対称モードの変形が場所に よって混在しており, 周期的な境界条件を想定し た単体モデルのそれと若干の差異が見られるが, 基本的には単体モデルを用いて説明可能である.

今後, 加工硬化を考慮した有限八ニカム材の圧縮応 力ーひずみ曲線を予測するため, 周期的な境界を想定 した単体理論モデルの拡張を行う予定である.

\section{文献}

(1) Gibson, L. J. and Ashby, M. F., Cellular solids, Pargamon Press, (1988).

(2) Papka, S. and Kyriakides, S., In-plane compressive response and crushing of honeycomb J. Mech. Phys. Solids, Vol.42, (1994), pp.1499-1532.

(3) Honig, A. and Stronge, W. J., In-plane dynamic crushaing of honeycomb: Part I Crush band initiation and wave trapping, Int. J. Mech. Sci., Vol.44, (2002), pp.16651696.

(4) Honig.A and Stronge.W.J In-plane dynamic crushaing of honeycomb: Part II Application to impact, Int. J. Mech. Sci., Vol.44, (2002), pp.1697-1714.

(5) Klintworth, J. W., Dynamic crushing of cellular solids, PhD dissertion, University of Cambridge, UK, (1988).

(6) Karagiozova, D. and Yu, T. X., Plastic deformation modes of regular hexagonal honeycombs under in-plane biaxial compression, Int. J. Mech. Sci., Vol.46, (2004), pp.14891515.

(7) Klintworth, J. W. and Stronge, W. J., Elasto-plastic yield limits and deformation laws for transversely crushed honeycombs, Int. J. Mech. Sci., Vol.30, (1988), pp.273292.

(8) Klintworth, J. W. and Stronge, W. J., Plane punch indentation of a ductile honeycomb Int. J. Mech. Sci., Vol.31, (1989), pp.359-378.

(9) MSC.Marc, User's manual 2003.

(10) Hayes, A. M. et al., Mechanics of linear cellular alloys, Mechanics of Materials, Vol.36, (2004), pp.691-713. 